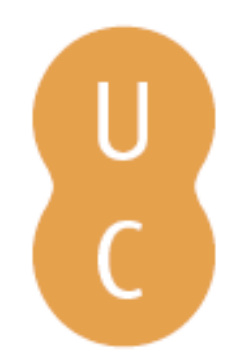

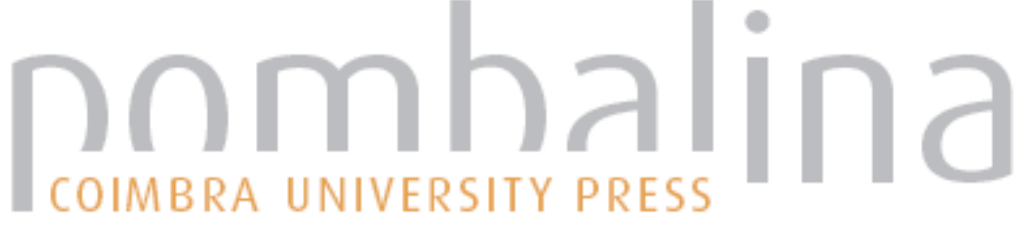

\section{Relance crítico sobre o Direito de Família português}

Autor(es): $\quad$ Corte Real, Carlos Pamplona

Publicado por: Imprensa da Universidade de Coimbra

URL

persistente:

URI:http://hdl.handle.net/10316.2/38882

DOI:

DOI:http://dx.doi.org/10.14195/978-989-26-1113-6_4

Accessed : $\quad$ 26-Apr-2023 11:56:18

A navegação consulta e descarregamento dos títulos inseridos nas Bibliotecas Digitais UC Digitalis, UC Pombalina e UC Impactum, pressupõem a aceitação plena e sem reservas dos Termos e Condições de Uso destas Bibliotecas Digitais, disponíveis em https://digitalis.uc.pt/pt-pt/termos.

Conforme exposto nos referidos Termos e Condições de Uso, o descarregamento de títulos de acesso restrito requer uma licença válida de autorização devendo o utilizador aceder ao(s) documento(s) a partir de um endereço de IP da instituição detentora da supramencionada licença.

Ao utilizador é apenas permitido o descarregamento para uso pessoal, pelo que o emprego do(s) título(s) descarregado(s) para outro fim, designadamente comercial, carece de autorização do respetivo autor ou editor da obra.

Na medida em que todas as obras da UC Digitalis se encontram protegidas pelo Código do Direito de Autor e Direitos Conexos e demais legislação aplicável, toda a cópia, parcial ou total, deste documento, nos casos em que é legalmente admitida, deverá conter ou fazer-se acompanhar por este aviso.

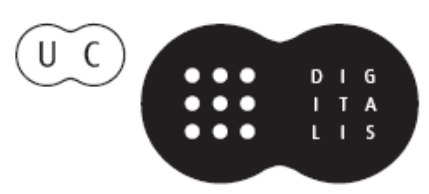




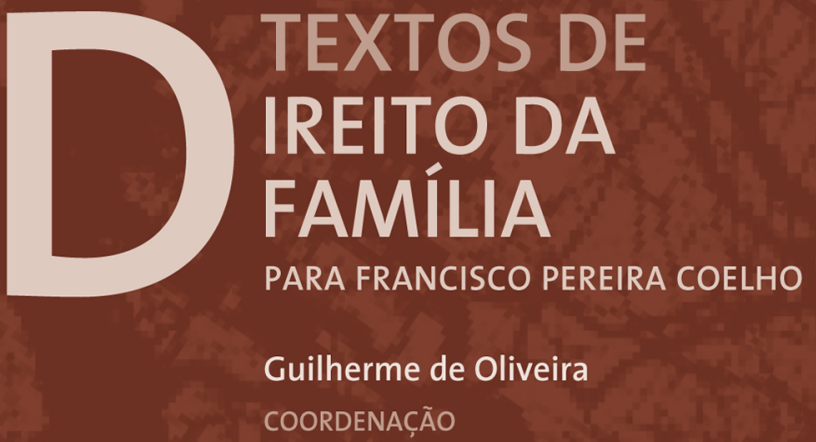




\section{RELANCE CRÍTICO SOBRE O DIREITO DE FAMÍLIA PORTUGUÊS}

Carlos Pamplona Corte Real Professor Aposentado da Faculdade de Direito da Universidade de Lisboa

Homenagem viva a um académico de eleição, um cientista profundo, um homem generoso, de quem tive a honra de ser discípulo, e que guardarei para sempre como imagem do dever ser docente.

\section{Sumário}

(a) A índole jurídica do Direito de Família; (b) A pretensa tipificação das situações jurídicas familiares; (c) A laicidade do casamento e a marcante influência do casamento católico; (d) O Casamento e a sua recondução a um contrato; (e) O estatuto da mulher casada; (f) Casamento e orientação sexual; (g) Os pretensos deveres conjugais; (h) Regime conjugal patrimonial geral e convencional: a respectiva problemática; (i) Casamento e União de Facto: analogia ou antagonismo do regime? (j) A eliminação da culpa na consecução do divórcio atestando o carácter livre da relação conjugal; (k) A prevalência do biologismo em termos de parentalidade; Conclusão.

Pretende este trabalho assumir-se como um ensaio analítico-critico do Direito de Família português que, inegavelmente, se perde em preconceitos e dilemas passadistas, que não ousa ultrapassar de uma forma radical. 
São vários os pontos que elencaremos, frisando relativamente a cada um deles as dificuldades denunciadas pelo nosso ordenamento e seus intérpretes.

\section{a) A índole jurídica do Direito de Família}

Partindo do pressuposto erróneo de que a família é a base da própria organização sócio-política, certo sector da doutrina vê neste ramo de direito um sector constituído por normas cogentes ou imperativas, que expressariam uma índole publicista do mesmo Direito de Família. Não parece poder relevar este ponto de vista, porque o Direito de Família parte da lídima afirmação de uma autonomia pessoal, intimista e geradora de uma convivencialidade perfeitamente recortada pelos sujeitos que a partilham. Nenhum ramo de direito poderá ser mais livre e íntimo que o Direito de Família, cabendo ao Estado, quando muito, a protecção da intimidade da vida familiar. Não será admissível que a vivência familiar possa ser imposta e não fruída.

Este é um dos dilemas que vêem subsistindo e que levam alguns autores a negar tal evidência, que a Constituição (CRP) bem garante, como se verá, quanto ao cariz da tutela da reserva da intimidade da vida familiar e da garantia do direito fundamental de constituir livremente família e de contrair, ou não, casamento (arts. ${ }^{\circ} 26 .^{\circ} \mathrm{e}$ 36. ${ }^{\circ}$ da CRP).

Concluindo, o Direito de Família é um ramo de direito privado, o mais "privado dir-se-ia", ainda que o Estado, reconhecendo a legitimidade dessa privacidade, a deva proteger e tutelar. 


\section{b) A pretensa tipificação das situações jurídicas familiares}

O artigo $1576^{\circ}$ do Código Civil Português (CC) elenca como fontes das relações jurídicas familiares, o casamento, o parentesco, a afinidade e a adopção. Tal circunstância leva a doutrina a querelar se seriam admissíveis outras situações familiares, discutindo a natureza taxativa do teor do referido preceito. Sempre sob o pressuposto do cariz para-publicista do Direito de Família. E daí as intermináveis discussões, v.g. sobre a recondução da união de facto a uma relação de família.

É no mínimo de estranhar que, neste específico ramo de direito, se não procure a essência do seu objecto e se pense que é possível taxativar as situações por ele abrangidas. A família cria-se e recria-se em tantas situações, pelo que parece perfeitamente inconseguível amarrar as suas manifestações coexistenciais a um leque pré-determinado de casos. Parece mais ajustado tecnicamente procurar-se nas situações contempladas no art. $.^{\circ} 1576 .^{\circ}$ a essência comum às mesmas, em ordem a admitir que possam relevar como tais outras que pisem os mesmos parâmetros, em termos analógicos. Então o que será uma situação jurídica familiar?

Crê-se, nesse tocante - já escrevi -, que um elemento constante nas situações legais enunciadas é a sua virtual ou efectiva perdurabilidade, que sublinha o carácter presumivelmente afectivo que lhes é inerente, ainda que o facto gerador seja vário, podendo ir v.g., de uma relação biológica a uma sentença judicial constituinte de um vínculo adoptivo.

Claro que a gradação do diferente cariz da origem, relevância social e da referida perdurabilidade do vínculo é vária. Mas, parecem ser esses aspectos - repete-se, perdurabilidade (virtual definitividade), inerentes ou presumidos laços afectivos mais ou menos expressivos, acto constitutivo significante biológica, vivencial, administrativa ou judicialmente, num cruzamento complexo porém 
relevante para a detecção de situações análogas ou afins igualmente eficazes na área familiar -, que corresponderão ao critério, sem dúvida complexo, que permitirá ao intérprete tomar uma situação como inserível no Direito de Família.

Dir-se-á que o critério é evanescente. Responder-se-á que terá que o ser perante a dinâmica hodierna do Direito de Família.

Lembra-se aqui que há uma autora brasileira, Maria Berenice Dias $^{1}$, que afirma dever falar-se não em Direito da Família mas em Direito das Famílias... E uma tal perspectiva permitiria abrir-se a porta do nosso sistema jurídico ao abarcar de novas realidades familiares, num mundo em mutação, onde o casamento já não tem de ser obrigatoriamente heterossexual, onde a união de facto, de facto nada tem, aproximando-se de uma união civil registável, onde o biologismo anda paredes meias com a procriação medicamente assistida (P.M.A.) e com uma perspectiva afectiva da parentalidade (...).

E será por isso que a nossa lei não retrata de forma compreensível a essência da coisa familiar (...).

É que liberdade e responsabilidade deverão ser sempre os índices que nortearão o jurista na detecção da normatividade jurídico-familiar, sem que uma conceptualização alheia à realidade, e/ou formal, propicie o acesso ao âmago do Direito de Família.

Teremos que nos "sorrir" quando lemos autores de nomeada, ainda hoje, controverterem a natureza jurídico-familiar da união de facto... Ainda o passadismo a marcar pontos sem a mínima razoabilidade. Como escreve Jemolo, a família "não pode ser reduzida a uma construção jurídica, pois lembra sobretudo afectos, diz mais respeito ao coração que à razão, sendo que o direito só é plenamente eficaz quando se trata de prescrever em matéria de valores económicos, do meu e do teu; ora, pertencendo ao domínio dos valores imateriais,

1 In "Manual do Direito das Famílias", 4. ${ }^{a}$ ed., Editora da Revista dos Tribunais, 2007 , p.p. 25 e ss. 
a família seria um instituto pré-jurídico que aparece sempre como uma ilha que o mar do direito pode tocar, mas apenas tocar"2.

Em conclusão, não tenha o ordenamento a veleidade de amarrar o Direito de Família na sua dimensão pessoal e inter-relacional, perfeitamente intangíveis.

\section{c) A laicidade do casamento e a marcante influência do casamento católico.}

Em Portugal, a Concordata de 1940, o Protocolo Adicional à mesma, de 15 de Fevereiro de 1975, e a Concordata de 2004, são um latente motivo de alguma perplexidade por parte dos cidadãos na apreensão da essência do casamento. O Código Civil admite ainda no art. $1587^{\circ}$, como modalidades do casamento, o casamento civil e o casamento católico, acrescentando o art. $1589^{\circ}$ a ideia de que se trataria de uma dualidade de casamentos. Tal leitura não será correcta, hoje em dia. O casamento civil é o único casamento a que se refere o art. $36^{\circ}$ da Constituição (CRP), como inequivocamente decorre do $\mathrm{n}^{\circ} 2$ do mesmo preceito, ainda que o nosso ordenamento reconheça eficácia também ao casamento religioso (que não apenas o católico) nos termos da Lei 16/2001, de 22 de Junho. Ou seja, o Estado Português já não se diz uma nação católica e respeita genericamente as religiões radicadas, que não contrariem a ordem pública interna, quanto aos respectivos casamentos, que apenas deverão ser precedidos da obtenção de um certificado prévio da capacidade civil matrimonial e, depois, devidamente sujeitos a uma controladora, no mero plano civil, transcrição no Registo Civil.

\footnotetext{
${ }^{2}$ Jemolo, A. C., "La Famiglia e il Diritto", in "Pagine Sparse di Diritto e Storiografia", Giuffrè, 1957, pp. 222 e ss.
} 
Dito isto, há contudo que reconhecer que, no tocante a aspectos conexos, por exemplo, com a indissolubilidade do casamento, ou com a heterossexualidade como pressuposto do vínculo conjugal, a natureza sacramental do casamento católico não deixou de pressionar o regime jurídico do casamento civil. Adiante especificar-se-á melhor a temática.

\section{d) O Casamento e a sua recondução a um contrato}

O artigo 1577..$^{\circ}$ do CC teve a veleidade de definir casamento como um contrato celebrado entre duas pessoas, em ordem a uma comunhão plena de vida. Disse-se veleidade porque não é tecnicamente ajustado o recurso a definições jurídicas na lei, porque dificilmente abarcarão todo o tipo de situações em causa, e por que não têm um conteúdo cogente, nem sequer normativo, mas meramente programático.

Quase sempre a definição peca tecnicamente e/ou, na amplitude das situações enquadradas. E, neste caso, é difícil vislumbrar-se no casamento um contrato, em termos tradicionais. Como se se pudesse contratar uma obrigação coexistencial de comunhão plena de vida; como se se pudesse contratar o exercício do afecto por forma perdurável, e fazendo face a necessárias e imprevisíveis alterações de circunstâncias; como se o casamento, a ser um contrato, pudesse circunscrever-se a um vínculo sinalagmático de direitos e deveres recíprocos, quando nem sequer é pensável a existência de direitos sobre pessoas.

O casamento é um projecto existencial, um acordo de vontades de índole por essência alterável no dia-a-dia da gestão familiar. Acto jurídico que não pode, porém, desdizer o que de mais respeitável tem a natureza humana, a sua índole pessoal e intimista, necessariamente, como se disse supra, inagarrável pelo direito e indisponível. 
Falar em contrato, ali onde a lei civil chega ao ponto de enunciar deveres conjugais (?), é de todo incompreensível. Retomar-se-á este problema quando se analisar a Lei do Divórcio, Lei n ${ }^{\circ} 61 / 2008$, de 31 de Outubro, lei que afastou a culpa da consecução do mesmo. Nem a ideia de contrato, nem a ideia de existência de deveres conjugais quadrariam com a essência do casamento.

Em suma, o casamento é um acto jurídico sem fronteiras no modo como os cônjuges o gerem, renovadamente, a nível diário, sendo ínvio o direito de interferir na programação de um dia-a-dia convivencial... O direito só pode intervir em casos limites e gravosos, como se verá adiante. Fica posta de lado a hipótese de transpor para o casamento, por exemplo, as regras específicas dos contratos sinalagmáticos perfeitamente inadequadas: reciprocidade no cumprimento das pretensas obrigações, resolução do vínculo por alteração das circunstâncias e toda uma panóplia de regras aplicáveis aos contratos bilaterais, que não são em absoluto pensáveis para o casamento, quanto mais não seja, por respeito ao princípio constitucional do livre desenvolvimento da personalidade e da insusceptibilidade de coisificação da vida a dois e da existência de direitos sobre pessoas.

Mais um momento de estupefacção ocorreria se quiséssemos pensar o dever de coabitação em termos imperativos e recíprocos, quando se está perante um acto, por essência absolutamente livre...

\section{e) O estatuto da mulher casada}

O estatuto jurídico da mulher casada, em termos sociais, é outra vexata questio que entravou, e continua a entravar, o processo evolutivo do Direito da Família português.

No passado, a chefia familiar, como é sabido, era atribuída ao marido, enquanto a mulher se quedava pelo governo doméstico, para além das substanciais restrições no campo da administração e dis- 
posição do património conjugal, mesmo quando próprio da mulher. Esta perspectiva terá sido aparentemente superada pela reforma do Código Civil de 1977, a qual na esteira da Constituição determinou a paridade ou igualdade dos cônjuges dentro do casamento, quer no domínio pessoal, nomeadamente no que à parentalidade diz respeito, quer no domínio patrimonial. E referiu-se aparentemente porque não só a sociedade ainda não assimilou adequadamente tal igualdade, como porque na própria leitura do Código Civil se podem entrever resquícios dessa situação anterior, ainda residual. Basta recordar o artigo $16766^{\circ}$, n. $^{\circ} 2$ que, na nova redacção conferida pela Lei $n .{ }^{\circ}$ 61/2008, de 31 de Outubro, continua a admitir que um dos cônjuges possa "renunciar de forma excessiva à satisfação dos seus interesses em favor da vida em comum, designadamente à sua vida profissional", encobrindo a situação concreta a que visa fazer face. "Renúncia excessiva" é um termo juridicamente no mínimo estranho; e está bem de ver que, no nosso contexto sociológico, dos cônjuges o renunciante (...) será tendencialmente o cônjuge mulher, a quem continua a ser "ocultadamente" reconhecida uma primazia na gestão do lar... Esta renúncia excessiva vai gerar a obtenção de uma pensão compensatória aquando da extinção do vínculo conjugal, como forma de fazer face àquilo que a doutrina chama de "enriquecimento sem causa" do cônjuge que não viu afectada a sua carreira e actividade profissional, normalmente o cônjuge marido. Ou seja, a nossa lei deixa latente vias de sustentação do estádio de não igualdade conjugal, não sendo o legislador inequívoco na assunção do seu próprio pensamento... ${ }^{3}$

3 Tomé, Maria João R. C. V., "Considerações sobre alguns efeitos patrimoniais do divórcio na Lei $\mathrm{n} .{ }^{\circ}$ 61/2008, de 31 de Outubro: (in)adequação às realidades familiares do Século XXI?" in "E foram felizes para sempre...?, Coordenação Sottomayor, Maria Clara e Féria de Almeida, Maria Teresa, Wolters Kluwer Portugal - Coimbra Editora, 2010, pp.180 e ss. 


\section{f) Casamento e orientação sexual}

Padece o nosso ordenamento de um claro preconceito homofóbico. Por mais que a Lei n. ${ }^{\circ}$ / $/ 2010$, de 31 de Maio, tenha admitido o casamento de pessoas do mesmo sexo; por mais que a Lei $n{ }^{\circ}$ 7/2001, de 11 de Maio, tenha admitido a União de Facto entre pessoas do mesmo sexo, corrigindo o teor da Lei n. ${ }^{\circ}$ 135/99, de 28 de Agosto (que ao consagrar pela primeira vez a União de Facto, a admitia apenas entre parceiros de sexo diferente), a verdade é que se viveram largos anos de completo impedimento jurídico quanto ao acesso familiar relativamente a casais de pessoas do mesmo sexo. Ainda hoje a lei civil, como adiante se verá, deixa no ar sequelas graves do referido preconceito homofóbico, no que à parentalidade nomeadamente diz respeito, quer em matéria de Adopção - artigo $3 .^{\circ}$ da Lei 9/2010, artigo 7. ${ }^{\circ}$ da LUF -, quer em matéria de P.M.A. artigo $6 .^{\circ}$ da Lei 32/2006, de 26 de Julho ${ }^{4}$.

Tudo remonta à velha questão (Teresa Pires e Helena Paixão) que o Tribunal Constitucional ${ }^{5}$, na altura, entendeu que não poderiam contrair casamento por não ser legível na Constituição qualquer assunção de uma posição permissiva, havendo como que uma abstenção constitucional com remissão em absoluto para o poder do legislador ordinário (ponto de vista partilhado, na altura, por Vital Moreira e Gomes Canotilho) ${ }^{6}$, ou seja, era como que passado um cheque em branco ao legislador ordinário (que se mantêm), desco-

${ }^{4}$ Nota do Coordenador: o texto foi escrito antes da aprovação, pela Assembleia da República, da adoção por casais do mesmo sexo.

5 Vd. Carlos Pamplona Corte Real, (Isabel Moreira e Luís Duarte d'Almeida), "O casamento entre pessoas do mesmo sexo: três pareceres sobre a inconstitucionalidade dos artigos $1577 .^{\circ}$ e $1628 .^{\circ}$, e), do Código Civil”, Almedina 2008, pp. 21 e ss.; os pareceres foram juntos ao processo de que resultou o Acórdão do Tribunal Constitucional n. ${ }^{\circ} 359 / 2009$, DR II Série, n. ${ }^{\circ} 214$, de 4 de Novembro.

${ }^{6}$ Cfr. Gomes Canotilho e Vital Moreira, "Constituição Portuguesa Anotada”, Tomo I, $4 .^{a}$ ed., Coimbra Editora, 2007, pp. 568 e ss.. 
nhecendo-se em absoluto, o artigo $13 .^{\circ},{ }^{\circ}{ }^{\circ} 2$, da Constituição, que a propósito do Princípio da Igualdade o impunha em termos de observância e respeito pela orientação sexual. Tal estado de coisas só viria a ser ultrapassado, com a Lei n. ${ }^{\circ}$ 9/2010, também ela escudada num acórdão em sentido radicalmente oposto do mesmo Tribunal Constitucional, o Acórdão n. ${ }^{\circ}$ 121/2010, de 8 de Abril.

Mudaram-se as normas jurídicas; ficou porém toda uma vivência social dificultante da viabilização inequívoca da possibilidade e acesso à conjugalidade de casais de pessoas do mesmo sexo. Adiante voltar-se-á ao tema, quando se analisar o regime jurídico da Adopção e da P.M.A. como já se fez referência acima, onde a inacessibilidade dos casais de pessoas do mesmo sexo é mais gritante. Rematando, o preconceito homofóbico continua a grassar (...) na nossa lei civil, agudizadamente no plano da parentalidade, o que contraria curiosamente a evolução ocorrida noutros países europeus, em que a parentalidade, em nome do superior interesse da criança, terá sido o problema primeiramente ultrapassado 7 .

\section{g) Os pretensos deveres conjugais}

A nossa lei civil, nos artigos $1672 .^{\circ}$ e seguintes, fala em deveres dos cônjuges, abrangendo os deveres de respeito, fidelidade, coabitação, cooperação e assistência. E o entendimento pacífico da doutrina portuguesa até ao surgimento da Lei $n .^{\circ}$ 61/2008 era o de que estes deveres conjugais seriam imperativos, sendo que a sua violação daria origem a uma situação culposa permissiva da obtenção de um divórcio, que então tinha a natureza de divórcio-sanção. Ninguém

7 Vd. Wintemute, Robert, "Igualdade na Parentalidade de Casais do Mesmo Sexo em Portugal: Co-Adoção e Adoção Conjunta", in "Famílias no Plural: alargar o conceito, largar o preconceito", ILGA Portugal, 2013, pp. 148 e ss.. 
ousava analisar da viabilidade desta exigência legal de cogência quanto aos deveres conjugais, esquecendo a doutrina em absoluto, o carácter indisponível da esfera jurídica pessoal dos cônjuges, e a sua insusceptibilidade de adstrição ao cunho imperativo destes deveres conjugais, que no mínimo embatiam fragorosamente no livre desenvolvimento da personalidade como valor constitucionalmente protegido. Assim foi sendo, no quietismo doutrinal com que se olhava a paz que se pretendia vinculasse, na instrumentalização dos deveres conjugais, a comunhão plena de vida dos cônjuges. Hoje em dia, a aberração da manutenção na lei civil dos deveres conjugais é mais evidente, porque a já referida Lei n. ${ }^{\circ}$ 61/2008 acabou com o divórcio-sanção baseado na culpa e acolheu o divórcio fracasso ou constatação da ruptura. Os artigos $1790 .^{\circ}$ a $1792 .^{\circ}$ demonstram bem que a culpa foi erradicada da pretensa "violação" dos tais "deveres" conjugais, o que torna de todo incompreensível a manutenção da terminologia, ou seja, a manutenção da referência a deveres que, no plano jurídico, pressupõem sempre uma adstrição sancionável no caso de incumprimento culposo. Não teve o legislador "coragem" de eliminar a referência aos deveres conjugais, reconhecendo que a comunhão plena de vida conjugal é um espaço de gestão livre e bicéfala, não sendo legítimo impor-se num campo tão marcadamente intimista a referência a vinculações imperativas. Não o permite aliás mesmo o artigo $26 .^{\circ}$ da Constituição; não o permite do mesmo modo a mencionada eliminação da culpa na consecução do divórcio. Realmente, é um contra-senso que um dever jurídico, eventualmente violado, não possa implicar a essência de culpa. Se tal não ocorre, como hoje em dia não ocorre com a lei do divórcio, é porque o dever não é um verdadeiro dever e terá um cunho quando muito programático $^{8}$.

\footnotetext{
${ }^{8}$ Sobre o ponto, leia-se, em sentido algo diverso, Jorge Duarte Pinheiro, in "O Direito da Família Contemporâneo", 4. ${ }^{a}$ ed., AAFDL, 2013, pp. 456 e ss.
} 


\section{h) Regime conjugal patrimonial geral e convencional: a res- pectiva problemática}

Não se faz ideia das perplexidades que o regime legal patrimonial a nível conjugal suscita. Por um lado, fixa a lei um regime geral que pretende compatibilizar com os regimes convencionais típicos e/ou atípicos, o que não parece tarefa facilmente exequível, porque um regime geral "torpedeado" por regimes plúrimos ditos típicos e atípicos perde exequibilidade e consequencialidade?.

Tem o legislador português necessidade, no que diz respeito aos aspectos gerais conexos com o regime das dívidas ou com o regime de administração e disposição dos bens, de fazer referências e remissões para os regimes de bens inseridos em convenção antenupcial ou supletivamente aplicados. Diz, por exemplo, que a alienação de um bem próprio de um dos cônjuges só é possível sem o consentimento do outro cônjuge no regime de separação de bens. E a questão é esta: e se se estiver perante um regime atípico em que, por exemplo, só um bem imóvel é dito ser comum, como se interpreta tal exigência por não se estar ante um verdadeiro e global regime de separação de bens? Também não faz sentido a existência de regimes tipificados ao lado de outros perfeitamente livres e atípicos. Qual a função dos regimes de bens que a lei tipificou? E com que intuito o fez? Mas há mais dificuldades. O regime de separação de bens, por exemplo, é compatível com a sucessão por morte do cônjuge sobrevivo, frustrando a aparência do objectivo visado pelos nubentes na convenção antenupcial ao estipularem-no. Também no regime de separação de bens é delicado entender como pode uma dívida ser tida por comunicável, quando os patrimónios são perfeitamente estanques; também no regime de comunhão de bens

${ }^{9}$ Cfr. Henriques, Sofia, "Estatuto Patrimonial dos Cônjuges - Reflexo da Atipicidade do Regime de Bens", Coimbra Editora, 2009, pp. 225 e ss.. 
(comunhão geral ou comunhão de adquiridos), alguns problemas são entrevisíveis: pense-se, por exemplo, no teor do artigo $1680 .^{\circ}$ que permite aos cônjuges constituirem depósitos em nome individual e movimentarem-nos livremente, sem qualquer tentativa de harmonização do regime bancário com um regime de bens comunitário eventualmente adoptado. Os bens depositados podem ser comuns e o depósito ser em nome individual... Ou seja, a coerência e a lógica não parecem imperar sempre, gerando-se dificuldades interpretativas. Por exemplo, e continuando, o património comum conjugal é considerado um património colectivo e não uma situação jurídica de compropriedade: será fácil apreender o alcance efectivo de tal distinção, que surge sem clareza sequer relevante no momento da extinção do vínculo? Por último, as convenções antenupciais, nos termos dos artigos $1698 .^{\circ}$ e seguintes do Código Civil, estão sujeitas ao princípio da imutabilidade do regime de bens. A ideia parece ser a de proteger mais os credores do que os próprios cônjuges, se bem que o artigo $1714 .^{\circ}$ crie excepções de todo contrastantes com essa preocupação, a saber, a possibilidade dos cônjuges celebrarem contratos de sociedade em que pelo menos um dos cônjuges pode suportar uma responsabilidade social ilimitada (cfr. arti. 8. do Código das Sociedades Comerciais). Enfim, uma encruzilhada de situações, dificultante do giro patrimonial conjugal, que seria mais fácil deixar em absoluto à livre disposição das partes, nomeadamente, no momento da celebração do casamento e na respectiva convenção antenupcial. Intrometendo-se em excesso, o legislador português cria amarras que tornam realmente difícil a extinção do vínculo conjugal, face às consequências casuístico-patrimoniais que são geradas no dia-a-dia pelo regime patrimonial complexo que a lei acolhe.

A solução parecia poder estar na absoluta devolução aos cônjuges da gestão dos aspectos patrimoniais próprios e comuns, em vida e por morte, sem intromissões abusivas e por vezes tecnicamente 
confusas da lei. Mais um ponto dificultante da apreensão do nosso sistema jurídico-familiar nas suas preocupações finalísticas.

\section{i) Casamento e União de Facto: analogia ou antagonismo do regime?}

Como já se disse, a União de Facto surgiu em 1999, com a Lei n. ${ }^{\circ}$ 135, para logo em 2001 com a Lei n. ${ }^{\circ}$ 7, de 31 de Maio, se ter admitido a aplicação da União de Facto a casais de pessoas do mesmo sexo. Este instituto surgiu de uma forma perversa, com o intuito de, mantendo o exclusivo acesso ao casamento por casais heterossexuais, criar um "casamento" de sub-condição para os casais de pessoas do mesmo sexo. Com a agravante de camuflar essa discriminação na circunstância de a União de Facto se aplicar também a casais heterossexuais. Havia, pois, uma alternativa colocada à disposição de casais de pessoas de sexo diferente, enquanto as pessoas do mesmo sexo se circunscreviam ao recurso à União de Facto, com um regime sub-alternizante e muito limitado do ponto de vista pessoal e patrimonial. Dois tipos de discriminação portanto, até ao aparecimento da Lei n. $^{\circ}$ 9/2010: por um lado, a inacessibilidade de pessoas do mesmo sexo ao instituto do casamento, por outro, um regime jurídico frágil para a União de Facto em termos consequenciais, aplicável, esse sim, a todos os casais; a alternativa entre Casamento e União de Facto era apenas deixada, como se disse supra, aos casais de pessoas de sexo diferente.

Quanto ao regime da União de Facto, para além da protecção em matéria de regime de férias, feriados, licenças e preferências de colocação próprias dos trabalhadores da Administração Pública ou com contrato de trabalho individual, para além de aspectos conexos com o IRS, apenas a tutela reportada à Segurança Social. A lei era completamente omissa em matéria de aspectos pessoais relacionais 
e afastava o companheiro sobrevivo do campo hereditário, circunscrevendo a sua tutela a um direito real de habitação periódico sobre a casa de morada de família e à possibilidade de obter uma pensão de alimentos à custa da herança do companheiro ou companheira.

Esta diferença de regime era obviamente intencional. O legislador quis discriminar o estatuto dignificante do Casamento do estatuto informal da União de Facto, embora como que "homenageasse" a comunhão vivencial livre correspondente à União de Facto com algumas prerrogativas sociais e patrimoniais. Nada que se compare com as amarras legais e com a tutela patrimonial e sucessória do casamento.

As coisas mantiveram-se assim até à Lei $n .^{\circ}$ 9/2010, como já foi dito, sendo que a União de Facto suscita latentemente a dúvida de saber o que vislumbra o legislador de diferente, para além da inexistência de um acto constitutivo formal, entre Casamento e União de Facto. É o mesmo afecto, é a mesma comunhão de vida, é o mesmo respeito recíproco, é o mesmo partilhar - quiçá - da vivência parental, donde parece decorrer que o legislador insiste na manutenção dos institutos porque... não os quer unificar... Porque não admitir uma única figura - o casamento constituído ou por via de um acto formal registal ou por via de uma convivência perdurável significante - e daí admitir-se uma aproximação de regimes jurídicos? Por que não admitir que o companheiro sobrevivo seja, por exemplo, herdeiro? Por que não admitir, por exemplo, que na União de Facto os companheiros possam recorrer aos regimes de bens conjugais se o estatuírem em escritura pública? Em suma, por que quer a lei duas figuras?

Certo é que tanto é querida tal distinção, a nível legislativo, que a doutrina chega ao ponto de negar índole familiar à União de Facto; não que tal circunstância tenha uma consequência palpável e entrevisível que seja facilmente concretizável, mas não se vê por que não inserir no leque das relações familiares do artigo $1576 .^{\circ}$ do 
Código Civil a União de Facto. Não se vê mesmo, e mais radicalmente - insista-se -, por que não admitir a unicidade dos institutos.

Neste tocante, conheço até uma voz ${ }^{10}$ - pelo menos - que entende que a União de Facto não deveria trazer, pura e simplesmente, nenhum efeito para os parceiros, porque as pessoas seriam livres de conviverem plenamente sem nenhumas consequências no plano jurídico, perspectiva essa aparentemente errónea porque não faz significar a própria convivencialidade no dia-a-dia como algo que o Direito deve couraçar, por expressar valores semelhantes aos do Casamento, porque o dever de respeito existe, porque a afectividade se exerce, porque a parentalidade pode estar presente também.

Enfim, louva-se o regime mais livre da União de Facto onde o Casamento devia beber inspiração, sendo que já cheguei a sustentar que a União de Facto quase poderia funcionar como paradigma do Casamento. Evidentemente que haveria sempre que acautelar, na União de Facto, pelo menos, a situação jurídica do desenlace de um ponto de vista pessoal e patrimonial, recorrendo aos princípios gerais de Direito, nomeadamente, boa-fé, enriquecimento sem causa, abuso de direito, etc.

\section{j) A eliminação da culpa na consecução do divórcio atestando o carácter livre da relação conjugal}

A Lei n. ${ }^{\circ}$ 61/2008 veio alterar a perspectiva ou visão do casamento, uma vez que, no artigo $1781 .^{\circ}$, elenca uma série de causas que nada têm a ver com a ideia de culpa, concluindo, na alínea d), com a referência a "quaisquer outros factos que, independentemente da culpa mostrem a ruptura definitiva do casamento". Esta ideia é retomada nos artigos $17900^{\circ}$ a $1792 .^{\circ}$, tornando-se claro que o divór-

${ }^{10}$ Henriques, Sofia, em conformidade com o respectivo ensino oral 
cio, mesmo sem o consentimento de um dos cônjuges, deixou de procurar castigar um pretenso cônjuge dito culpado, para apenas se preocupar com a regulamentação das consequências pessoais, parentais e patrimoniais da extinção do vínculo. Inclusive, o divórcio por mútuo consentimento é actuável nas Conservatórias do Registo Civil, e só quando há divergências entre os ex-cônjuges no tocante aos acordos que o artigo $1775 .^{\circ}$ exige (ou se não acautelarem os respectivos interesses), é que o tribunal será chamado a intervir, ou, ainda, quando não haja assentimento no que diz respeito à obtenção do próprio divórcio, ou esteja em causa um acordo de regulação das responsabilidades parentais que deva ser controlado pelo Ministério Público.

Mas voltando atrás, a lei do divórcio, dum ponto de vista consequencial, não alterou o teor dos artigos $17900^{\circ}$ e $1791 .^{\circ}$, quanto à aplicabilidade do regime de comunhão de adquiridos em qualquer caso, e a qualquer dos cônjuges, e quanto à perda das liberalidades ou benefícios recebidos do outro cônjuge ou de terceiro em vista do casamento. Não é necessário, portanto, ser cônjuge-culpado, ou principal culpado, o que deixou de ser indagado pelo Juiz, para que essas consequências sejam aplicáveis.

Mas então como explicar tal circunstância? Parece que a explicação óbvia terá a ver com a lei querer, tão-só, impedir o enriquecimento de um dos cônjuges à custa do outro ou à custa de liberalidades em função do casamento, porque desapareceu a causa da respectiva aquisição - o próprio casamento. Pretende o legislador repor, por isso e apenas, a situação quo ante sem benefícios injustificados para nenhum dos consortes.

O artigo $1792 .^{\circ}$ tem sido como que a aparente tábua de salvação dos autores ${ }^{11}$ que continuam a sustentar que esta lei do divórcio continua a penalizar o cônjuge-culpado. Determina tal preceito que

${ }^{11}$ Duarte Pinheiro, Jorge, ob. cit., 2013, pp. 630 e ss.. 
"o cônjuge lesado tem o direito de pedir a reparação dos danos causados pelo outro cônjuge nos termos gerais da responsabilidade civil e nos tribunais comuns," mas o que este preceito sublinha não tem a ver com a culpa, que a lei erradicou, conexa com pretensas violações dos deveres conjugais. Tê-lo-á, sim, com danos causados por um dos cônjuges, como se de um terceiro se tratasse, v.g. em termos de ofensas à integridade física, homicídio, factos ilícitos que se enquadrem, por exemplo, no crime da violência doméstica, mas que não têm directamente a ver com os deveres conjugais mas com uma relação entre quaisquer cidadãos, a que se exige, porém, uma especial diligência face à intimidade da vivência que partilha com o outro. Ou seja, é uma questão que deve ser resolvida nos tribunais comuns - a competência, aqui, é dos tribunais comuns, e não dos tribunais de família -, precisamente porque a problemática da culpa aqui é ponderada já fora da órbita dos meros deveres conjugais, embora a situação conjugal possa agravar a responsabilidade civil, para além da criminal, que possa estar em causa.

A Lei n. ${ }^{\circ}$ 61/2008 veio finalmente - pode afirmar-se peremptoriamente - afastar a relevância da culpa no divórcio, facilitando o desenlace e quase que se bastando com a demonstração da falência do casamento. Alguns ordenamentos, v.g. como o espanhol e o alemão ${ }^{12}$, contentam-se com o próprio pedido judicial, ou seja, reconhecem o divórcio a pedido, sem averiguar problemáticas de culpa mas só as consequências pessoais e patrimoniais da extinção da relação conjugal, entendimento que se sustenta poder ser inclusive aplicado no âmbito da Lei n. ${ }^{\circ} 61 / 2008$. A verdade é que a nossa jurisprudência continua apegada à ideia de que a não demonstração da falência conjugal implicaria a inconsecução do resultado da acção.

12 Cfr. Pamplona Corte Real, Carlos e Silva Pereira, J., "Direito de Família: Tópicos para uma Reflexão Crítica” AAFDL, 2011 pp. 21 e ss.; vd. ainda Dias Costa, Eva, "Da Relevância da Culpa nos Efeitos Patrimoniais do Divórcio", Almedina, 2005, pp. 70 e ss. 
Mais dois pontos poderiam ser referidos relativamente à lei do divórcio.

1. O exercício das responsabilidades parentais pelos ex-cônjuges: nesse tocante, o artigo $1906 .^{\circ}$ não se afastou muito da anterior redacção, estabelecendo apenas que para questões de particular importância as responsabilidades parentais devam ser exercidas em comum por ambos os progenitores, mas que já quanto aos actos da vida corrente do filho haveria uma predominância do progenitor com quem o filho reside, estabelecendo-se (n. ${ }^{\circ} 3$ do artigo $1906 .^{\circ}$ ) que o outro progenitor com quem ele se encontra temporariamente não deve contrariar as orientações educativas mais relevantes tal como elas são definidas pelo progenitor residente. A guarda alternada continua a ser aparentemente vedada, e continua também a dar-se predominância a um dos ex-cônjuges na orientação da vida do filho, o que parece violentar o n. ${ }^{\circ} 5$ do artigo $36 .^{\circ}$ da CRP. A solução que pareceria mais equitativa e respeitadora da paridade parental constitucionalmente acolhida parecia ser a de uma guarda tendencialmente partilhada, porque não há razão alguma para se dar prevalência aos critérios educativos de um dos progenitores, a menos que haja razões gravosas que a tal obriguem.

2. O outro ponto tem a ver com a já referida contribuição excessiva de um dos cônjuges para a satisfação dos interesses da vida em comum, em matéria de encargos de direito familiar e parental, pois o cônjuge que, ainda que acordadamente, fique em casa com tarefas domésticas e de guarda dos filhos afecta a possibilidade da conversão da sua vida no caso de ruptura do casamento, beneficiando o cônjuge que o não faça. Tal circunstância gera o direito a uma pensão compensatória, diz a lei, bem difícil de calcular. Esta pensão compensatória visará fazer face a um dito enriquecimento sem causa obtido à 
custa do ex-cônjuge tido por renunciante, sendo que é difícil computar o montante de um tal enriquecimento e entrever nesse tocante uma solução que seja justa na superação do impasse que possa ter sido criado. Esta situação da pensão compensatória é analisada com alguma profundidade pela doutrina $^{13}$, nomeadamente na sua articulação com a pensão de alimentos, sendo que o artigo 2016. ${ }^{\circ}$-A estabelece vários critérios conexos com o montante dos alimentos devidos ao ex-cônjuge com custódia.

Só uma nota para dizer que, apesar da eliminação da culpa, o artigo $2016 .^{\circ}, \mathrm{n} .^{\circ} 3$, afirma de uma forma evanescente que, por manifestas razões de equidade, o direito a alimentos pode ser negado. Parece uma reminiscência da ideia de culpa (veja-se, também, o artigo 2019. ${ }^{\circ}$, quanto à cessação da obrigação alimentar), parecendo o legislador preocupado em "limpar" as consequências do anterior casamento após o divórcio.

Em suma, e concluindo, continua a haver uma excessiva intromissão judicativa na decisão de questões que por exemplo a mediação familiar certamente e com mais facilidade superaria. A verdade é que muitos são os problemas que este tipo de matéria suscita dos quais avulta a síndrome da alienação parental, que está longe de ser resolúvel com eficácia e espírito de unidade familiar. Muitos problemas, como se vê; e reconheça-se que não se está perante falhas técnicas mas perante dificuldades de cariz psicossocial que justificam uma ponderação específica porque está em causa, naturalmente, o interesse superior das crianças. A única coisa que poderá dizer-se é que a solução jurisprudencial neste domínio continua

13 Vd. Tomé, Maria João R. C. V., ob. cit., pp. 180 e ss.;

Cfr. também Sottomayor, Maria Clara, "Uma Análise Crítica do Novo Regime Jurídico do Divórcio”, obra supra citada, pp. 38 e ss.. 
a ser, via da regra, a entrega dos filhos menores à custódia das mães (...).

\section{k) A prevalência do biologismo em termos de parentalidade?}

Mantém a lei portuguesa uma sobrevalorização do critério biológico de definição do vínculo parental sobre o critério afectivo. Tal decorre do teor do artigo $1796 .^{\circ}$ do CC, conjugado com o artigo $1801 .^{\circ}$ do CC. Não sendo inequívoca a perfeita harmonia do recurso aos exames de sangue e a outros métodos científicos com a relevância dada ao facto do nascimento - poderão até implicar conclusões distintas quanto à filiação -, a verdade é que a nossa doutrina reclama e continua a proclamar a pretensa preponderância dos critérios biológicos na definição da parentalidade. Esse ponto de vista traz consequências, como se verá, quanto à hierarquização e funcionalidade da parentalidade por via adoptiva.

E o certo é que o biologismo acaba por se contradizer a si próprio, pois, por razões conexas com a chamada "paz das famílias", relevam critérios como o do pater is est (artigo 1826. ), presunção que determina a paternidade do marido da mãe, para não falar já na prescritabilidade das chamadas acções de estado. Tais circunstâncias buscam a sua razão de ser, e em última instância, ainda na própria visão biologista. Na mesma linha de pensamento, e apesar da índole subsidiária que o artigo $4 .^{\circ}$, n. $^{\circ} 1$, da Lei n. $.^{\circ} 32 / 2006$, de 26 de Julho, atribui à parentalidade decorrente da P.M.A., é ainda em nome do biologismo que tal regime é explicado.

No que toca à adopção, diz Jorge Duarte Pinheiro ${ }^{14}$ que ela é desenhada legalmente sobre o modelo da parentalidade biológica, dando também especial ênfase a esta parentalidade.

14 Duarte Pinheiro, Jorge, ob. cit., pp. 129 e ss. e 183 e ss.. 
A nossa lei mantém-se realmente agarrada a critérios passadistas, sendo que a evolução em termos de direito comparado se vem fazendo no sentido do reconhecimento da igual valia jurídica da parentalidade dita afectiva, em nome de outro valor tido por mais relevante, que é o interesse superior da criança.

Veja-se então a forma como a nossa lei trata o acesso à parentalidade por via adoptiva e/ou por via da P.M.A.: a) no que à adopção diz respeito, a Lei n. ${ }^{\circ} 31 / 2003$, de 22 de Agosto, continua a padecer das vicissitudes anteriores, nomeadamente no que concerne ao dificultoso processo de constituição do vínculo adoptivo que culmina numa sentença judicial, no rígido estabelecimento duma extinção dos vínculos do filho adoptivo com a família natural, ao estabelecimento de uma absurda discriminação entre filhos adoptados plenamente e restritamente e, por fim, à permissão da figura da co-adopção exclusivamente na adopção plena conjunta por casais heterossexuais casados ${ }^{15}$. Curioso que a adopção, "plagiando" a parentalidade biológica(?), parece poder ser singular (artigos 1979. ${ }^{\circ}$, n. $^{\circ}$ 2 , e $1992 .^{\circ}$ ) o que acarreta, não obstante, alguma controvérsia sobre a aplicabilidade a candidatos homossexuais da adopção singular;

b) no que diz respeito à P.M.A. o tratamento legal deixa muito a desejar em termos científicos: desde logo porque a infertilidade é condição sine qua non do acesso a tais técnicas (artigo $4 .^{\circ}, \mathrm{n} .^{\circ} 2$, da Lei $n .^{\circ} 32 / 2006$ ), o que exclui quer as mulheres solteiras quer os casais de pessoas do mesmo sexo (artigo $6 .^{\circ}$ da mesma Lei); depois porque, no que concerne à maternidade de substituição que

15 Cfr. Pamplona Corte Real, Carlos e Silva Pereira, J., ob. cit., pp. 195 e ss. e 211 e ss.. No que respeita a co-adopção, a solução contida no Projecto de Lei n. ${ }^{\circ}$ 278/XII, que permitia a co-adopção pelo cônjuge ou unido de facto do mesmo sexo, aprovado na generalidade, acabou por não o ser na especialidade após um trajecto de difícil aceitação política, o que traz a Portugal uma posição delicada ante a condenação da Áustria por Acórdão do Tribunal Europeu dos Direitos do Homem, de 9 de Fevereiro de 2013, precisamente por ter, na altura, uma legislação similar à portuguesa, discriminatória portanto quanto aos casais unidos de facto do mesmo sexo. 
a lei inclusivamente veda (artigo $8 .^{\circ}$ ), foi adoptada uma solução que desconsidera em absoluto, ao atribuir-se à mãe hospedeira a maternidade, o superior interesse da criança; depois porque não é atentamente pensado o regime dos embriões excedentários, assim como o da inseminação post mortem, para nem se referenciar a própria discriminação entre a infertilidade feminina a nível ovular e a nível uterino (pois só aquelas são abrangidas pela Lei) ${ }^{16}$.

Do exposto decorre, concluindo, a incompletude e a infelicidade jurídica das soluções legais, num complexo normativo incoerente e retrógrado. O ponto culminante, como já foi supra dito, está no não acesso dos casais de pessoas do mesmo sexo, tanto à adopção (artigo $3,^{\circ}$ da Lei n. ${ }^{\circ}$ 9/2010, de 31 de Maio e artigo $70^{\circ}$ da L.U.F. com a redacção que lhe foi dada pela Lei $n .^{\circ}$ 23/2010, de 30 de Agosto) como à P.M.A. (artigo 6. ${ }^{\circ}$ da Lei n. ${ }^{\circ} 32 / 2006$ ).

Rematando, é notória a dificuldade da nossa lei em superar o preconceito biologista, ou seja, a ideia perfeitamente ultrapassada de uma complementaridade heterossexual para um adequado exercício da função parental, sendo que tal dificuldade está bem denunciada na Lei do Apadrinhamento Civil (Lei n. ${ }^{0}$ 103/2009, de 11 de Setembro), em que o legislador chega ao ponto de cismar uma adopção restrita entrevendo uma hipotética relação virtual entre as famílias apadrinhante e natural.

\section{Conclusão}

Feito este percurso analítico do sistema jurídico-familiar português pode inequivocamente reconhecer-se que o mesmo oscila entre os tradicionais valores do passado e alguma tendencial, ainda que

\footnotetext{
16 Por todos veja-se Pamplona Corte Real, Carlos, e Silva Pereira, J., ob. cit., pp. 233 e ss. e bibliografia aí citada a pp. 249 e ss..
} 
pouco expressiva, aproximação às novas realidades familiares. E se a hermenêutica jurídica assenta numa unidade axiológica inspirante do sector em análise, forçoso é reconhecer que, entre alguns avanços e muito mais recuos, o Livro IV do Código Civil será indiscutivelmente "o livro do nosso descontentamento"!... Tanto por fazer, tanto por corrigir, tanto por assumir! 